\title{
PATRIMONIO CULTURAL. CONCEPTOS, DEBATES Y PROBLEMAS
}

\section{IGNACIO GONZÁLEZ-VARAS}

\author{
Madrid, Ediciones Cátedra, 2015, 256 páginas
}

ISBN: 978-84-37634-17-3

Resulta una ardua tarea presentar el panorama general relativo al patrimonio cultural, elaborar un texto que aborde el concepto y su aplicación de forma integral, dado lo extenso y complejo de este término. No obstante, este, ampliamente analizado y convenientemente tratado desde una perspectiva crítica, sirve de firme hilo conductor a la publicación de Ignacio González-Varas, quien expone con maestría el concepto de patrimonio cultural, su génesis y su papel en nuestro mundo actual.

González-Varas ejerce su actividad docente como Catedrático de Composición Arquitectónica en la Universidad de Castilla-La Mancha, habiendo llevado a cabo asimismo su actividad académica en otros centros tanto nacionales como internacionales. Contando con una dilatada experiencia investigadora, sus numerosos proyectos, publicaciones y colaboraciones se centran principalmente en la Historia del Arte y la Arquitectura así como en la Teoría del Patrimonio Cultural. Esta obra puede considerarse la síntesis y, a su vez, actualización de su archiconocida monografía Conservación de bienes culturales. Teoría, historia, principios y normas, publicada en la misma editorial en 1999.

Como respuesta al creciente proceso de patrimonialización, a través del cual se ha hecho efectiva la difusión del concepto en cuestión, surge esta nueva obra en la que se pone de manifiesto la visibilidad del patrimonio en distintos ámbitos como espacio de frontera entre lo puramente académico y la propia sociedad, ámbitos ambos en los cuales cobra una importancia capital. Siguiendo un esquema ordenado y accesible González-Varas traza un marco de referencia para el conocimiento del patrimonio desde el planteamiento del propio concepto hasta el desarrollo del término en las últimas décadas, desde una perspectiva altamente especializada pero que no deja de ser asequible y didáctica en su exposición.

Un primer bloque de cuatro capítulos sirve como aproximación a la construcción conceptual del patrimonio y los procesos asociados a su evolución. Bajo esta dinámica, el primero de ellos se centra en la fundamentación teórica del patrimonio, cuyo discurso aborda el origen de este, su evolución histórica y expansión. Atiende a sus relaciones con la cultura, su aplicación a los bienes y su comunicación, para, finalmente, reflexionar acerca de la 
actualización del concepto con la mencionada patrimonialización y las vinculaciones con el pasado y la memoria. Toma el relevo el segundo capítulo, el cual refiere la dimensión institucional y el marco normativo del patrimonio cultural. Ello lo articula en tres niveles, como son, el ámbito regional-estatal, la esfera internacional, y el círculo local. De esta manera, tratará el patrimonio mundial, los patrimonios nacionales y su legislación, así como el patrimonio de las comunidades y su alcance popular y social. Un tercer capítulo se ocupa de poner sobre la mesa el papel del patrimonio cultural en la construcción de identidades, bien de una nación, una identidad local o particular, o un conjunto global entendido como patrimonio cultural de la humanidad, este, en su dimensión más universal. En el capítulo subsiguiente, es la relación entre patrimonio cultural y turismo la protagonista del texto, pues, como parte del consumo de la cultura, encontramos un amplio desarrollo de la actividad turística en su segmentación cultural. Es por ello que aquí se analizan los orígenes, la experiencia, la repercusión y efectos de este fenómeno sobre los bienes culturales y su conservación, tratando asimismo el impacto del turismo sobre los agentes implicados.

Todo ello sirve de base a tres capítulos consecutivos, centrados en la conservación del patrimonio, un ámbito interdisciplinar en el que confluyen una multiplicidad de visiones, métodos y procedimientos. Sobre la teoría sobre los valores culturales del patrimonio versa el quinto capítulo, en el que se expone la problemática asociada a la valoración social de este y a la proveniente del ámbito académico-científico. La definición de los valores del patrimonio constituye el primer paso para dotar de significación a sus elementos a través de una visión crítica que permita interpretar dichos valores patrimoniales en sus diversas categorías: valoraciones históricas, contemporáneas, de autenticidad. El sexto capítulo aborda una cuestión cuya polaridad se refiere al equilibrio histórico y estético de los bienes: la conservación y restauración del objeto artístico. Asunto en el que radica una problemática de actualidad como es el encuentro entre la tradición y las nuevas prácticas. En esta línea, plantea teorías y metodologías de intervención sobre el patrimonio: la conservación, el debate sobre la restauración, las aportaciones teóricas y el papel de los actores, conservadores y restauradores.

En los últimos cuatro capítulos se aplican criterios expuestos a cuatro tipologías patrimoniales que el autor apunta como campos de estudio y práctica específicos. En el primero de ellos ofrece una síntesis del patrimonio edificado, que comprende tipologías asociadas a la arquitectura y la ciudad. Aunando los patrimonios arquitectónico, arqueológico, industrial y urbano -este último, en la consideración de los conjuntos históricos-, propone un recorrido objetivo por su conservación y restauración. A continuación, se dedica al análisis 
del trinomio territorio, naturaleza y patrimonio, dando lugar a un capítulo en el que aborda el paisaje cultural como unidad emergente e integradora de estas realidades, de su protección y conservación. Dando paso al patrimonio inmaterial o etnológico, hace hincapié en el valor de la cultura tradicional, los usos y costumbres populares como muestra identitaria de la diversidad de los pueblos y grupos sociales, disertando acerca de la conservación de este patrimonio y su reactivación. Por último, destina un capítulo al patrimonio bibliográfico y documental. Como parte de la cultura material, el testimonio escrito se erige como categoría per se, es decir, como una tipología propia dentro de la clasificación patrimonial cuyo valor documental se hace extensivo a expresiones variadas que abarcan otras formas y soportes de diversa naturaleza.

Finalmente, una completa bibliografía, secuenciada según la organización temática, sirve de referencia al lector para profundizar en los aspectos expuestos. A esto sumamos la selección de textos incluida al final de cada capítulo, donde se amplían las fuentes de conocimiento acerca de las cuestiones tratadas, incorporando una serie de textos normativos y legislativos junto a otros de producción académica o de carácter crítico, todo lo cual se enmarca en esta línea de conocimiento del patrimonio desde diversas áreas.

En conclusión, esta obra acerca al lector a la evolución del patrimonio cultural en el tiempo histórico: desde el nacimiento del concepto y su expansión, a la conexión de los propios bienes con su pasado, y su análisis y puesta en valor en el presente. Todo ello, ofreciendo una visión global sobre el patrimonio, una percepción múltiple y diversa producto de una valoración eminentemente crítica, constituyendo esta una aportación fundamental para la comprensión integral de la dialéctica inherente al patrimonio cultural, sus conceptos, debates y problemas.

María del Castillo García Romero

Universidad de Sevilla 